\title{
Evaluation of Financial Performance: A Comparative Study of Selected Commercial Banks in Ethiopia
}

\author{
By Mesfin Agonafer Zeleke \\ Accounting \& Finance, Mathematics \& MBA, Department of Management, \\ College of Business \& Economics, Dire Dawa University \\ Banbul Shewakena \\ Assistant Professor of Financial Management, Department of Management, \\ College of Business and Economics, Dire Dawa University \\ Eshetu Hailemariam, \\ Department of Management, College of Business and Economics, Dire Dawa University
}

\begin{abstract}
This study is aimed at evaluating the financial performance and ranking the performance of the selected commercial banks in Ethiopia for the period 2011 to 2017. To meet the objective of the study, secondary sources of data, such as annual reports of the banks have been utilized. After collecting the necessary data, appropriate financial ratios, descriptive statistical techniques and average, percentage, and proportion were employed for analyzing, interpreting, ranking, transformation of data and giving a condensed picture of the collected data. Accordingly, the results of the study revealed that the financial performance of the bank in a measure of profitability $\mathrm{CBE}, \mathrm{DB}$ and $\mathrm{WB}$ occupies the first three positions respectively. In a liquidity measure WB ranks first, BOA ranks second and UB ranks the third position. In a risk and solvency measure NIB, BOA and UB covers the first three positions. In an efficiency measurement CBE occupies the first, WB occupies the second and NB occupies the third position. In the overall measure of banks financial performance WB, NIB and UB occupies the first three positions respectively.
\end{abstract}

Keywords: Financial performance, ratios, ranking, banking sector, Ethiopia

DOI: $10.7176 / \mathrm{EJBM} / 11-7-06$

Publication date:March $31^{\text {st }} 2019$

\section{INTRODUCTION}

a) Background of the study

Economy of a country whether it is developed or developing highly supported by service giving organization, among them financial market and financial intermediaries account the larger proportion, but due to financial markets are not well developed in a country like Ethiopia, their economic development and prosperity of the country largely relay on financial intermediaries (banks, insurance companies and micro-finance institutions) particularly commercial banks which accounts eight percent of the total and that accept deposits and channels those deposits in to lending activities. So, the performance of banks through financial statements should be monitored closely and frequently to improve the wealth of the bank, to attract interested parties like investors, creditors and managers, and also largely to improve the economic development of the country. Moreover, it is of great importance to keenly observe the performance of the banks and their compliance with the regulatory requirement.

Even if, financial statement represents historical data and did not consider inflation, Banks prepare financial statement, particularly Balance sheet and Income statement for internal use or for management to make decision about the future and also for external users or to attract mostly investors and creditors. Analyst uses financial statements to measure the performance of the banks and also to indicate the attractiveness and weakness of banks.

Financial statement analysis begins with a set of financial ratios designed to reveal the strength and weaknesses of a company as compared with other companies in the same industry, and to show whether its financial position has been improving or deteriorating over time (Brigham and Houston, 1999).

Ratio analysis is a widely used tool of financial analysis. The term ratio is refers to the relationship expressed in mathematical terms between two individual figures or group of figures connected with each other in some logical manner and are selected from financial statements of the concern. It helps to express the relationship between two accounting figures in such a way that users can draw conclusions about the performance, strengths and weakness of a firm.

The history of banking sector in Ethiopia undergone five distinct periods, the first event was establishment in 1906 of the Bank of Abyssinia, marking the advent of banking into the country. The second event was Italian occupation in 1936, when following liquidation of the Bank of Ethiopia, a broad colonial banking network, extended to encompass all Italian possessions in the Horn of Africa and closely linked with the metropolitan 
financial system, was set up in the country. The third event was, in 1943, establishment of the State Bank of Ethiopia, marking the rebirth of the Ethiopian independent banking. This occurred during World War II after liberation of the country. The fourth event was the revolution of 1974, which wiped out the monarchy, nationalised companies and shaped a socialist banking two-tier model suited to Ethiopia, the whole credit system being based on the central bank and three state-owned financial institutions, each of them enjoying monopoly in its respective market. The fifth event was the collapse of socialist regime followed by a financial sector reform and liberalization according to Monetary and Banking Proclamation of 1994, which legalized investment in the domestic private banking sector and it brings the beginning of new era in the Ethiopian banking sector.

Currently, seventeen commercial banks and one publicly owned specialized banks are operating in Ethiopia as compared to one government owned commercial bank and one specialized banks before the measures took place. Of the, seventeen commercial banks, one is publicly owned and sixteen (16) are privately owned banks. It is clear that, Commercial Bank of Ethiopia (CBE), Awash International Bank (AIB), Dashen Bank (DB), Bank of Abyssinia (BOA), Wegagen Bank (WB), United Bank (UB) and Nib International Bank (NIB) are commercial banks operating in Ethiopia before 2000GC. Therefore, the aim of this study is to compare financial performance of selected commercial banks in Ethiopia regarding to their liquidity position, profitability position, risk \& solvency position, and efficiency position.

\section{b) Statement of the problem}

Sound financial health of a bank and its financial performance analysis are a guarantee to its creditors, managers, shareholders, depositors, employees and to the economy at large.

Creditors can use analysis of financial performance whether to agree on the terms and conditions of debt finance. Managers can use the analysis to assess and compare the performance of different divisions and the company as a whole. They have the chance to compare their company against competitors. Shareholders use analysis of financial performance to assist them to make, buy and sell decisions, compare the performance of their investments with that of similar companies, and to assess the quality of managers. Depositors and employees at least need to know the liquidity and profitability of the bank. Finally, the proper function of these interests and sound financial function results an economic growth in the country.

Hence regulators and other concerned body mobilize their resources and put their effort to maintain and control the rampant interest of these integrated participants in the banking industry.

Even if, financial sectors of developing countries mainly banks characterized by underutilization of resources, the economy of a country like Ethiopia is closely or highly related with the performance of commercial banks. So that, to provide the information needs of stakeholders and to improve the performance of the country and the banks as well through frequent performance evaluation, different researchers involved.

Although few studies have been made as related to financial performance analysis of commercial banks, such as performance comparison between the government and private banks, insurance, and other financial institutions such analysis in the case of the comparison between selected commercial banks with liquidity, profitability, risk $\&$ solvency and efficiency as a parameter still remains unexplored. The researchers has tried to fill this lack of evidence by extending the issue to the specific context of the companies.

Therefore, the aim of this study is to evaluate and compare financial performance of the selected commercial banks with each other throughout the study period, to provide some comments by observing several financial ratios, analysing trends of various elements of financial statement of the selected commercial banks' doing seven years performance results, and to improve its banking business. Hence, this became the basis of the study.

\section{c) Objective of the study}

The objective of the study is Evaluation of financial performance; A comparative study of selected commercial banks in Ethiopia.

\section{METHODOLOGY OF THE STUDY}

The study was entirely depends on secondary sources of data; in one hand, different literatures were extracted to establish a theoretical framework of the study and on the other, audited financial statements of the sample banks were the major sources of data. The study, Moreover, delimited to 2011-2017 financial reports of the bank. After collecting the data from the bank's website, the data were analyzed using (1) At the end of each parameters estimation we calculate the cumulative rank and transformation of data (if the data's are not identical data) of the selected banks by using average (or mean), percentage and proportion and (2) methods of the financial ratio analysis to measure, describe and analyze the performance of the banks were employed. These ratios include:

\section{a) Profitability Ratios}

Profitability ratios are generally considered to be the basic bank financial ratio in order to evaluate how well bank is performing in terms of profit. For the most part, if a profitability ratio is relatively higher as compared to the competitor(s), industry averages, guidelines, or previous years' same ratios, then it is taken as indicator of better performance of the bank. In the banking literature, different scholars in measuring bank performance have used many profitability ratios (Iqbal et al., 2005). The main performance indicators computed for banks are: 


\section{i. $\quad$ Return on Assets (ROA)}

Return on assets indicates the profitability on the assets of the firm after all expenses and taxes (Van Horne 2005). It is a common measure of managerial performance (Ross, Westerfield, Jaffe 2005). It measures how much the firm is earning after tax for each dollar invested in the assets of the firm. That is, it measures net earnings per unit of a given asset, moreover, how bank can convert its assets into earnings (Samad \& Hassan 2000). Generally, a higher ratio means better managerial performance and efficient utilization of the assets of the firm. ROA is calculated as under:

ROA $=$ Net Profit after Tax / Total Asset.

\section{ii. Return on Equity (ROE)}

Return on equity indicates the profitability to shareholders of the firm after all expenses and taxes (Van Horne 2005). It measures how much the firm is earning after tax for each dollar invested in the firm. In other words, ROE is net earnings per dollar equity capital. (Samad \& Hassan, 2000). It is also an indicator of measuring managerial efficiency (Ross 2002). By and large, higher ROE means better managerial performance and high growth companies. ROE is calculated as under:

$\mathrm{ROE}=$ Net profit after tax / Shareholders' Equity

\section{iii. Profit to Expenses Ratio (PER)}

It measures the operating profitability of the bank with regards to its total operating expenses. Operating profit is defined as earnings before taxes and operating expenses means total non-interest expenses. The ratio measures the amount of operating profit earned for each dollar of operating expense. The ratio indicates to what extent bank is efficient in controlling its operating expenses. A higher PER means bank is cost efficient and is making higher profits (Samad \& Hassan 2000). PER is calculated as under:

PER $=$ Profit before tax $/$ Operating Expenses

\section{iv. Net Interest Margin (NIM)}

Net interest income is the difference between interest income and interest expense. It is the gross margin on a bank's lending and investment activities. The higher the ratio the cheaper the funding or the higher the margin the bank is obtaining. A bank's net interest margin is a key performance measure that drives ROA (Peters, Raad \& Sinkey, 2004). NIM is calculated as under:

$\mathrm{NIM}=$ (Interest Income - Interest Expense $) /$ Total Asset

\section{v. Return on Deposit (ROD)}

To most financial analysts, Return on Deposit (ROD) is one of the best measures of bank profitability performance. This ratio reflects the bank management ability to utilize the customers' deposits in order to generate profits (Tarawneh, 2006). ROD is calculated as under:

ROD $=$ Net Profit after Tax / Total Deposit

\section{b) Liquidity Ratios}

Liquidity ratios indicate the ability of the firm to meet recurring financial obligations. Liquidity is important for the firm to avoid defaulting on its financial obligations and, thus, to avoid experiencing financial distress (Ross, Westerfield, Jaffe 2005). These ratios measure ability of the firm to meet its short-term obligations, maintain cash position, and collect receivables. In general, sense, the higher liquidity ratios mean bank has larger margin of safety and ability to cover its short-term obligations. Because saving accounts and transaction deposits can be withdrawn at any time, there is high liquidity risk for both the banks and other depository institutions. Banks can get into liquidity problem especially when withdrawals exceed new deposit significantly over a short period of time (Samad \& Hassan 2000). There are several measures for liquidity

\section{i. Cash to Deposit Ratio (CDR)}

Cash in a bank vault is the most liquid asset of a bank. Therefore, a higher CDR indicates that a bank is relatively more liquid than a bank, which has lower CDR. Depositors' trust to bank, is enhanced when a bank maintains a higher cash deposit ratio. CDR is calculated as under:

$\mathrm{CDR}=\mathrm{Cash} /$ Deposit.

\section{ii. Loan to Deposit Ratio (LDR)}

Loan to deposit is the most important ratio to measure the liquidity condition of the bank. Bank with Low LDR is considered to have excessive liquidity, potentially lower profits, and hence less risk as compared to the bank with high LDR. However, high LDR indicates that a bank has taken more financial stress by making excessive loans and shows risk that to meet depositors' claims bank may have to sell some loans at loss. LDR is calculated as under:

\section{$\mathrm{LDR}=\mathrm{Loan} /$ Deposit}

\section{iii. Loan to Asset Ratio (LAR)}

Loan to assets ratio is also another important ratio that measures the liquidity condition of the bank. LAR measures the percentage of assets that are tied up in loans. That is, it gauges the percentage of total assets the bank has invested in loans. The higher is the ratio the less the liquidity is of the bank. The bank with low LAR is considered to be more liquid as compared to the bank with higher LAR. However, high LAR is an indication of potentially 
higher profitability and hence more risk. LAR is calculated as under: LAR $=$ Loan $/$ Asset

\section{c) Credit Risk and Solvency Ratios}

This is a class of ratios, which measures the risk and solvency of the bank. These ratios are also referred to as gearing, debt, or financial leverage ratios. The extent to which a firm relies on debt financing rather equity is related with financial leverage. These ratios determine the probability that the firm default on its debt contracts. The more the debt a firm has the higher is the chance that firm will become unable to fulfil its contractual obligations. In other words, higher levels of debt can lead to higher probability of bankruptcy and financial distress. Although, debt is an important form of financing that provided significant tax advantage, it may create conflict of interest between the creditors and the shareholders (Ross, Wedsterfield, and Jaffe 2005). If the amount of assets is greater than amount of its all types of liabilities, the bank is considered to be solvent. Deposits constitute major liability for any type of bank whether Islamic or conventional. To gauge risk and solvency of the bank we use:

\section{i. Debt Equity Ratio (DER)}

The extent to which firm uses debt. It measures ability of the bank capital to absorb financial shocks. In case, creditors default in paying back their loans or the asset values decrease bank capital provides shield against those loan losses. A bank with lower DER is considered better as compared to the bank with higher DER. DER is calculated as under:

\section{DER = Total Debt / Shareholders' Equity}

\section{ii. Debt to Total Asset Ratio (DTAR)}

It measures the amount of total debt firm used to finance its total assets. It is an indicator of financial strength of the bank. It provides information about the solvency and the ability of the firm to obtain additional financing for potentially attractive investment opportunities. Higher DTAR means bank has financed most of its assets through debt as compared to the equity financing $\&$ the bank involved in more risky business. DTAR is calculated as under: DTAR $=$ Total Debt $/$ Total Assets

\section{iii. Equity Multiplier (EM)}

How many times the total assets are of the shareholders' equity is measure by equity multiplier. In other words, it indicates the amount of assets per dollar of shareholders' equity. Higher value of EM means that bank has used more debt to convert into assets with share capital. Generally, the higher is the EM the greater is the risk for a bank. EM is calculated as under:

\section{$\mathrm{EM}=$ Total Asset $/$ Total Shareholders' Equity}

\section{iv. Non- Performing Loans to Total Loan Ratio (NPLTL)}

Non-performing loans are loans that are no longer producing income for the bank that owns them. Loans become non-performing when borrowers stop making payments and the loans enter default. The exact classification can vary from institution to institution, but a loan is usually considered to be non-performing after it has been in default for three consecutive months. Banks often report their ratio of non-performing loans to total loans as a measure of the quality of their outstanding loans. A smaller NPLTL ratio indicates smaller losses for the bank, while a larger NPLTL ratio can mean larger losses for the bank as it writes off bad loans. NPLTL is calculated as under:

NPTL $=$ Non-performing Loans/Total Loans

\section{d) Efficiency ratios}

The presence of inefficiencies is considered as an inherent feature of banking. According to Turati (2003:2), "banks are regarded as firms that emerge as a result of some sort of market imperfections; hence they bring about a certain degree of inefficiency with respect to perfect competitive outcome". Banking efficiency is important at both macro and micro levels and in order to allocate resources effectively, banks should be sound and efficient Hassen (2005). These ratios measure how effectively and efficiently the firm is managing and controlling its assets. Higher value of these ratios is taken as good indicator, which means firm is doing well. Ratios used to measure are:

\section{i. Asset Utilization (AU)}

How effectively the bank is utilizing all of its assets is measured by assets utilization ratio. The bank is presumably said to using its assets effectively in generating total revenues if the AU ratio is high. If the ratio of AU is low, the bank is not using its assets to their capacity and should either increase total revenues or dispose of some of the assets (Ross, Westerfield, and Jaffe 2005). Total revenue of the bank is defined as net spread before provision plus all other income. AU is calculated as under:

$\mathrm{AU}=$ Total Revenue/Total Asset

\section{ii. Income Expense Ratio (IER)}

Income to expense is the ratio that measures amount of income earned per dollar of operating expense. This is the most commonly and widely used ratio in the banking sector to assess the managerial efficiency in generating total income vis-à-vis controlling its operating expenses (Samad\& Hassan 2000). High IER is preferred over lower one as this indicates the ability and efficiency of the bank in generating more total income in comparison to its total operating expenses. Total income in the study is defined as net spread earned before provisions plus all other income while the Other Expenses in the income statement are treated as total operating expense for the study. IER 
is calculated as under

IER $=$ Total income $/$ Total Operating Expenses

\section{iii. Operating Efficiency (OE)}

$\mathrm{OE}$ is the ratio that measures the amount of operating expense per dollar of operating revenue. It measures managerial efficiency in generating operating revenues and controlling its operating expenses. In other words, how efficient is the bank in its operations (Ross, Wedsterfield, and Jaffe 2005). Lower OE is preferred over higher OE as lower $\mathrm{OE}$ indicates that operating expenses are lower than operating revenues. Operating revenue is defined as net spread earned before provisions plus fee, brokerage, commission, and for ex income. Other expenses is defined same as we defined in the previous ratio. OE is calculated as under:

$\mathrm{OE}=$ Total Operating Expenses / Total Operating Revenue

\section{DATA ANALYSIS AND INTERPRETATION}

In this part of the research, the collected financial data have been analyzed, discussed and interpreted accordingly and then different ratio analysis has been undertaken.

\section{a) Ratio Analysis}

As it was already mentioned, a bank's balance sheet and income statement are valuable information sources to evaluate financial strengths and weaknesses of a bank and its business trends. Although the birr amounts found on these statements provide valuable insights into the financial performance and condition of the bank, the researcher typically used data from them to develop financial ratios to evaluate the bank financial performance. In all of the remainder of this chapter, the researcher used key ratios, liquidity, profitability, efficiency, and credit risk \& solvency, commonly used by bank analysts to evaluate different dimensions of financial performance of selected commercial Banks to compare with each other and make time series analysis over recent seven years. So the study first calculated ratios of each of the selected commercial banks from their own consolidated financial statements and compare these ratios with each other in each year, and finally identifying the best performing bank in the industry.

\section{i. Profitability ratios}

Profitability is a management concept with the objective of assessment bank's results from efficiency point of view both for entirely activity and for differently management compounds. From conceptual point of view, profitability represents the modality to achieve the major goal of bank's activity, respectively the maximization of profit in minimization risk conditions.

\section{a. Return on Assets (ROA)}

ROA is defined as the ratio of profit after tax to total asset. It reflects the efficiency with which banks deploy their assets. The higher the ROA, the most profitable is the bank.

Table 3.1 Return on Assets (In percentage)

\begin{tabular}{|l|l|l|l|l|l|l|l|l|l|}
\hline & $2010 / 11$ & $2011 / 12$ & $2012 / 13$ & $2013 / 14$ & $2014 / 15$ & $2015 / 16$ & $2016 / 17$ & Average & Rank \\
\hline CBE & 2.51 & 3.41 & 3 & 2.82 & 2.87 & 2.53 & 2.11 & 2.75 & 4 \\
\hline AIB & 3.25 & 3.01 & 2.47 & 2.80 & 2.56 & 2.39 & 2.39 & 2.70 & 5 \\
\hline DB & 3.07 & 3.73 & 3.08 & 3.24 & 2.94 & 2.54 & 2.18 & 2.97 & 2 \\
\hline BOA & 2.50 & 2.47 & 2.61 & 2.40 & 2.10 & 2.23 & 2.11 & 2.35 & 7 \\
\hline WB & 4.01 & 4.02 & 3.1 & 3 & 2.57 & 2.32 & 2.54 & 3.08 & 1 \\
\hline UB & 3 & 3.39 & 2.82 & 2.34 & 1.96 & 1.96 & 1.74 & 2.46 & 6 \\
\hline NIB & 3.46 & 3.46 & 3.13 & 2.92 & 2.54 & 2.25 & 2.46 & 2.89 & 3 \\
\hline
\end{tabular}

(Researchers own computation from audited financial statement)

It is presented above in table 3.1 that the average value of ROA of WB is $3.08 \%$ which is the highest amongst its peer group and is thus ranked first followed by DB with an average value of $2.97 \%$ and NIB with average value of $2.89 \%$. The average of net income to total asset ratio of BOA is $2.35 \%$ which is lowest among the selected banks and is ranked last.

\section{b. Return on Equity (ROE)}

This ratio indicates how bank can generate profit with the money shareholders have invested. The higher value of this ratio shows higher financial performance. Like ROA, this ratio is also indicator for managerial efficiency. 
Table 3.2 Return on Equity (In percentage)

\begin{tabular}{|l|l|l|l|l|l|l|l|l|l|}
\hline & $2010 / 11$ & $2011 / 12$ & $2012 / 13$ & $2013 / 14$ & $2014 / 15$ & $2015 / 16$ & $2016 / 17$ & Average & Rank \\
\hline CBE & 45.91 & 71.40 & 63.80 & 62.16 & 65.89 & 71.73 & 24.03 & 57.85 & 1 \\
\hline AIB & 26.98 & 23.90 & 21.23 & 23.81 & 20.26 & 18.90 & 20.85 & 22.28 & 3 \\
\hline DB & 32.27 & 35.67 & 29.67 & 27.41 & 24.93 & 21.65 & 18.93 & 27.22 & 2 \\
\hline BOA & 27.60 & 22.35 & 23.91 & 17.71 & 15.90 & 17.64 & 18.41 & 20.50 & 4 \\
\hline WB & 24.17 & 20.92 & 17.8 & 16 & 14.60 & 13.39 & 15.86 & 17.53 & 6 \\
\hline UB & 25.72 & 27.04 & 23.47 & 17.66 & 16.68 & 16.36 & 15.17 & 20.30 & 5 \\
\hline NIB & 21.05 & 18.73 & 17.18 & 15.97 & 15.48 & 14.17 & 17.48 & 17.15 & 7 \\
\hline
\end{tabular}

(Researchers own computation from audited financial statement)

It is a measure of the profitability of a bank. Profit after tax is expressed as a percentage of equity and an average score of $57.85 \%, 27.22 \%$, and $22.28 \%$ were registered for CBE, DB, and AIB and it has given them the chance to hold first to third of the available ranks respectively. On the other hand, NIB is the one who held the seventh rank with an average rate of return of $17.15 \%$ to its shareholders for their investment.

\section{c. Profit to Expense Ratio (PER)}

This ratio indicates profitability of the firm with regard to its total non-interest expenses. A high value of this ratio indicates that bank could make high profit with a given expenses.

Table 3.3 Profit to Expense Ratio

\begin{tabular}{|l|l|l|l|l|l|l|l|l|l|}
\hline & $2010 / 11$ & $2011 / 12$ & $2012 / 13$ & $2013 / 14$ & $2014 / 15$ & $2015 / 16$ & $2016 / 17$ & Average & Rank \\
\hline CBE & 2.59 & 4.03 & 3.07 & 2.26 & 2.26 & 2 & 1.73 & 2.56 & 1 \\
\hline AIB & 2.37 & 1.80 & 1.23 & 1.34 & 1.08 & 0.93 & 0.90 & 1.38 & 3 \\
\hline DB & 2.03 & 2.22 & 1.64 & 1.56 & 1.11 & 0.94 & 0.71 & 1.46 & 2 \\
\hline BOA & 1.15 & 1.17 & 1.37 & 1.01 & 0.80 & 0.71 & 0.65 & 0.98 & 7 \\
\hline WB & 2.12 & 1.82 & 1.38 & 0.96 & 0.82 & 0.72 & 0.76 & 1.23 & 4 \\
\hline UB & 2.06 & 1.84 & 1.31 & 0.9 & 0.62 & 0.62 & 0.58 & 1.13 & 6 \\
\hline NIB & 1.78 & 1.79 & 1.32 & 1.05 & 0.94 & 0.79 & 0.93 & 1.23 & 4 \\
\hline
\end{tabular}

(Researchers own computation from audited financial statement)

According to this ratio Commercial bank of Ethiopia is at the top position with an average of profit to expense ratio of 2.56 times followed by Dashen Bank and Awash International bank with an average 1.46 times and 1.38 times respectively whereas Bank of Abyssinia is at the last position with an average of 0.98 times.

\section{d. Return on Deposit (ROD)}

This ratio shows percentage of return on each dollar of customers' deposit. In other word, it indicates the effectiveness of bank in converting deposit into net earnings

Table 3.4 Return on Deposit (In percentage)

\begin{tabular}{|l|l|l|l|l|l|l|l|l|l|}
\hline & $2010 / 11$ & $2011 / 12$ & $2012 / 13$ & $2013 / 14$ & $2014 / 15$ & $2015 / 16$ & $2016 / 17$ & Average & Rank \\
\hline CBE & 3.21 & 4.51 & 3.80 & 3.55 & 3.62 & 3.37 & 2.80 & 3.55 & 5 \\
\hline AIB & 4.48 & 4.12 & 3.35 & 3.84 & 3.31 & 3.07 & 3.06 & 3.60 & 4 \\
\hline DB & 3.82 & 4.62 & 3.82 & 4.02 & 3.68 & 3.19 & 2.72 & 3.70 & 3 \\
\hline BOA & 3.00 & 3.00 & 3.12 & 2.97 & 2.59 & 2.76 & 2.58 & 2.86 & 7 \\
\hline WB & 5.43 & 5.82 & 4.50 & 3.79 & 3.46 & 3.16 & 3.41 & 4.22 & 1 \\
\hline UB & 3.82 & 4.41 & 3.50 & 2.96 & 2.38 & 2.49 & 2.16 & 3.10 & 6 \\
\hline NIB & 4.78 & 4.91 & 4.30 & 3.96 & 3.45 & 2.87 & 3.14 & 3.92 & 2 \\
\hline
\end{tabular}

(Researchers own computation from audited financial statement)

In table $3.4, \mathrm{WB}$ is on the top position with highest average of $4.22 \%$ followed by NIB and DB with an average of $3.92 \%$ and $3.70 \%$ respectively. BOA scored the last position with least average of $2.86 \%$ due to the managements of the BOA are inefficient in transforming customers deposit in net earning relative to other banks.

\section{e. Net Interest Margin (NIM)}

Net Interest Margin measures the amount of operating income to earning asset. Higher the NIM ratio, higher is the quality of the management decision. Because higher operating income is the result of higher interest income or comparative lower interest expense, which is charged upon the earning assets such as Short-term Investment, loans and investment. 
Table 3.5 Net Interest Margin (In percentage)

\begin{tabular}{|l|l|l|l|l|l|l|l|l|l|}
\hline & $2010 / 11$ & $2011 / 12$ & $2012 / 13$ & $2013 / 14$ & $2014 / 15$ & $2015 / 16$ & $2016 / 17$ & Average & Rank \\
\hline CBE & 2.59 & 3.16 & 3.66 & 3.51 & 3.90 & 3.96 & 3.53 & 3.47 & 4 \\
\hline AIB & 1.67 & 2.92 & 2.97 & 2.78 & 3.26 & 3.66 & 3.99 & 3.04 & 6 \\
\hline DB & 1.78 & 2.79 & 2.69 & 2.58 & 3.01 & 2.73 & 2.94 & 2.65 & 7 \\
\hline BOA & 4.60 & 4.13 & 3.20 & 3.71 & 3.52 & 3.84 & 3.91 & 3.84 & 1 \\
\hline WB & 2.66 & 3.62 & 3.97 & 3.73 & 4.10 & 4.21 & 4.19 & 3.78 & 2 \\
\hline UB & 2.51 & 3.64 & 3.55 & 3.69 & 3.92 & 4.05 & 4.17 & 3.65 & 3 \\
\hline NIB & 3 & 2.63 & 3.15 & 3.67 & 3.53 & 3.66 & 4.61 & 3.46 & 5 \\
\hline
\end{tabular}

(Researchers own computation from audited financial statement)

It is presented in the above table 3.5 that the average value of net interest margin to total assets ratios of BOA is $3.84 \%$ which is the highest amongst its peer group and is thus ranked first. BOA is followed by WB and UB with an average score of $3.78 \%$ and $3.65 \%$ respectively. The average of net interest margin to total assets ratios of $\mathrm{DB}$ is $2.65 \%$ which is lowest among its group and is ranked last.

\section{f. Overall ranking of Profitability measure}

The Group Ranking of all the selected banks under the profitability parameter was shown in table 3.6 below. The group ranking is based on the average of individual bank's profitability sub-parameter ranks. The contribution of each bank for specific sub-parameter was converted into hundred percent primarily for not affecting the contribution of one specific-parameter by the other (to make each specific-parameter independent of each other), secondly to protect their contribution for the overall profitability performance as well as the overall performance besides calculating the overall profitability result conveniently. The table below shows the profitability ratios by type of banks and the overall rank position of the banks regarding to profitability.

Table 3.6 overall profitability measure

\begin{tabular}{|l|l|l|l|l|l|l|l|}
\hline & ROA & ROE & PER & ROD & NIM & Average & Rank \\
\hline CBE & 14.32 & 31.64 & 25.68 & 14.23 & 14.52 & 20.08 & 1 \\
\hline AIB & 14.06 & 12.19 & 13.84 & 14.43 & 12.72 & 13.47 & 4 \\
\hline DB & 15.47 & 14.89 & 14.64 & 14.83 & 11.09 & 14.18 & 2 \\
\hline BOA & 12.24 & 11.21 & 9.83 & 11.46 & 16.08 & 12.16 & 7 \\
\hline WB & 16.04 & 9.59 & 12.34 & 16.91 & 15.83 & 14.14 & 3 \\
\hline UB & 12.81 & 11.10 & 11.33 & 12.42 & 15.28 & 12.59 & 6 \\
\hline NIB & 15.06 & 9.38 & 12.34 & 15.72 & 14.48 & 13.40 & 5 \\
\hline
\end{tabular}

(Researchers own computation from audited financial statement)

On the basis of group averages of five ratios of profitability measure as expressed in table 3.6, CBE was at the top position with group average of $20.08 \%$, followed by DB and WB with an average of $14.18 \%$ and $14.14 \%$ respectively. BOA scored the lowest position with $12.16 \%$ average ranks due to its poor performance in Return on asset, profit to expense and return on deposit relative to the other banks.

\section{ii. Liquidity ratios}

The liquidity ratios measure the capability of bank to meet its short-term obligations. Generally, the higher value of this ratio indicates that firm has larger margin of safety to cover its short-term obligations. Among the various liquidity measures, the study uses the following three liquidity ratios.

\section{a. Loan to Deposit Ratio (LDR)}

Loan to deposit ratio indicates the percentage of the total deposit locked into non-liquid asset. A higher loan to deposit ratio indicates that a bank takes more financial stress by making excessive loan. Therefore, lower loan deposit ratio is always preferable to higher loan deposit ratio. This low value of loan deposit ratio also indicates effectiveness of mediation function of bank.

Table 3.7 Loan to Deposit Ratio (In percentage)

\begin{tabular}{|l|l|l|l|l|l|l|l|l|l|}
\hline & $2010 / 11$ & $2011 / 12$ & $2012 / 13$ & $2013 / 14$ & $2014 / 15$ & $2015 / 16$ & $2016 / 17$ & Average & Rank \\
\hline CBE & 84.77 & 102.4 & 96.48 & 103.6 & 109.7 & 113.82 & 114.95 & 103.67 & 7 \\
\hline AIB & 47.75 & 56.00 & 58.83 & 56.93 & 63.99 & 63.75 & 68.86 & 59.44 & 5 \\
\hline DB & 51.69 & 56.03 & 54.72 & 53.11 & 57.07 & 54.82 & 63.73 & 55.88 & 1 \\
\hline BOA & 54.61 & 57.61 & 55.29 & 56.59 & 54.05 & 59.93 & 68.16 & 58.03 & 2 \\
\hline WB & 48.85 & 60.35 & 60.73 & 53.90 & 59.53 & 63.08 & 65.61 & 58.86 & 3 \\
\hline UB & 54.02 & 60.46 & 58.42 & 53.92 & 58.11 & 62.56 & 67.84 & 59.33 & 4 \\
\hline NIB & 53.64 & 63.56 & 68.26 & 69.71 & 71.61 & 61.56 & 66.33 & 64.95 & 6 \\
\hline
\end{tabular}

(Researcher own computation from audited financial statement)

From the above table 3.7 , DB is on the top position with least average of $55.88 \%$ followed by BOA with average of $58.03 \%$ and $\mathrm{WB}$ with average $58.86 \%$. DB, BOA and WB are more concerned about the protection of depositors and creditors. CBE scored the lowest position. The extent in which CBE relies on debt financing is 
higher than other banks rely on debt financing and also the loan provision of the industry is highly dominated by CBE due to the policy of National Bank of Ethiopia.

\section{b. Cash to Deposit Ratio (CDR)}

Another measure of liquidity of the bank is the cash to deposit ratio. The higher the ratio the better is the liquidity position of the bank, therefore, the more is the confidence and trust of the depositors in the bank as compared to the bank with lower CDR.

Table 3.8 Cash to Deposit Ratio (In percentage)

\begin{tabular}{|l|l|l|l|l|l|l|l|l|l|}
\hline & $2010 / 11$ & $2011 / 12$ & $2012 / 13$ & $2013 / 14$ & $2014 / 15$ & $2015 / 16$ & $2016 / 17$ & Average & Rank \\
\hline CBE & 17.83 & 12.19 & 11.33 & 7.81 & 8.84 & 10.96 & 10.27 & 11.32 & 2 \\
\hline AIB & 6.45 & 4.41 & 4.62 & 4.25 & 5.07 & 3.13 & 3.75 & 4.53 & 7 \\
\hline DB & 6.54 & 6.38 & 7.04 & 8.05 & 7.92 & 8.15 & 5.62 & 7.10 & 6 \\
\hline BOA & 7.12 & 10.79 & 9.78 & 13.64 & 11.27 & 8.36 & 8.26 & 9.89 & 3 \\
\hline WB & 38.37 & 19.25 & 13.78 & 22.25 & 14.58 & 15.52 & 17.76 & 20.22 & 1 \\
\hline UB & 10.82 & 10.72 & 10.74 & 10.06 & 10.74 & 9.06 & 6.79 & 9.85 & 4 \\
\hline NIB & 8.84 & 8.91 & 10.42 & 10.77 & 8.78 & 7.88 & 7.07 & 8.95 & 5 \\
\hline
\end{tabular}

(Researcher own computation from audited financial statement)

In the above table $3.8, \mathrm{WB}$ is seen to be relatively at the top with highest average of $20.22 \%$ followed by CBE with an average score of $11.32 \%$ and BOA with an average score of $9.89 \%$. On the other hand, AIB is the least performer in this regard with an average score of $4.53 \%$.

\section{c. Loan to Asset Ratio (LAR)}

The loans to assets ratio measure the total loans outstanding as a percentage of total assets. The higher this ratio indicates a bank is loaned up and its liquidity is low. The higher the ratio, the more risky a bank may be to higher defaults.

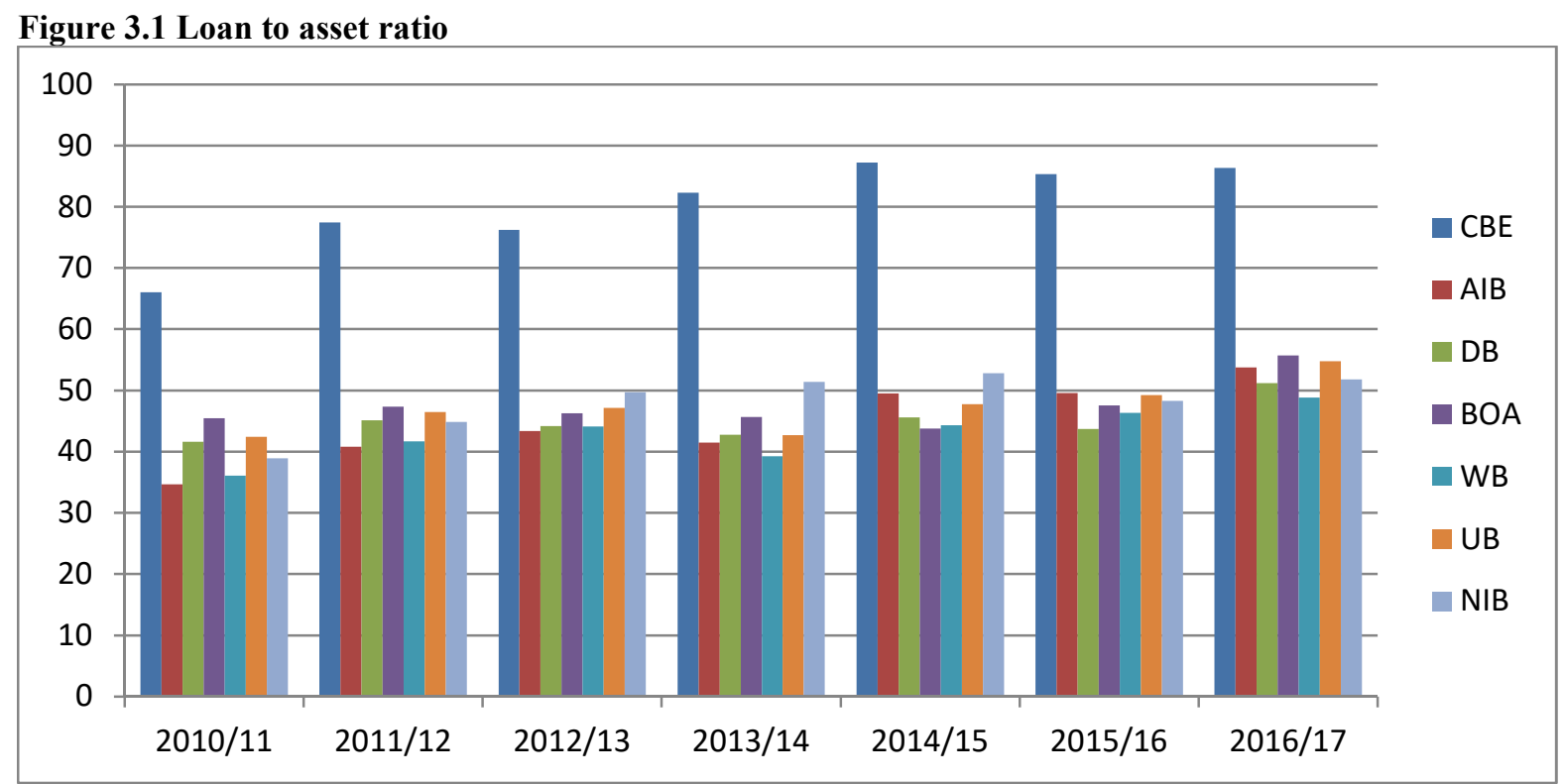

On the bases of financial ratio analysis or on the above figure, WB stood at first position regarding to LAR with an average of $42.95 \%$ followed by AIB with $44.74 \%$ and DB with $44.87 \%$ of average scores, while CBE secured the least position with an average score of $80.14 \%$ due to the loan provision of the banking industry highly dominated by commercial bank of Ethiopia because of the policy of National Bank of Ethiopia and also due of the ages of the assets of the CBE decreases its value than the rest of the banks which are in operation for less than three decades.

\section{d. Overall ranking of Liquidity measure}

The group ranking of all the selected banks under the Liquidity parameter was shown in Table 3.8 below. The group ranking is based on the average of individual bank's liquidity sub-parameter ranks, but from the subparameter CDR was transformed into a meaningful form by taking the reciprocal (1/CDR) for the purpose of comparison with LDR and LAR. Moreover, the contribution of each bank for specific sub-parameter was converted into $100 \%$ primarily for not affecting the contribution of one specific-parameter by the other (to make each specific-parameter independent of each other), secondly to protect their contribution for the overall liquidity performance as well as the overall performance besides calculating the overall liquidity result conveniently. The table below shows the average of loan to deposit, cash to deposit and loan to assets by type of banks and the overall 
rank position of the banks regarding to liquidity.

Table 3.9 overall liquidity measure (In percentage)

\begin{tabular}{|l|l|l|l|l|l|}
\hline & LDR & CDR & LAR & \multicolumn{1}{c|}{ Average } & Rank \\
\hline CBE & 22.53 & 10.85 & 22.54 & 18.64 & 7 \\
\hline AIB & 12.92 & 27.13 & 12.58 & 15.86 & 6 \\
\hline DB & 12.14 & 17.31 & 12.62 & 14.02 & 5 \\
\hline BOA & 12.61 & 12.43 & 13.33 & 12.79 & 2 \\
\hline WB & 12.79 & 6.08 & 12.08 & 10.32 & 1 \\
\hline UB & 12.89 & 12.48 & 13.29 & 12.89 & 3 \\
\hline NIB & 14.12 & 13.72 & 13.56 & 13.80 & 4 \\
\hline
\end{tabular}

On the basis of group averages of three ratios of liquidity as expressed in table 3.9, WB was at the top position with group average of $10.32 \%$, followed by BOA with average of $12.79 \%$ and UB with average of $12.89 \%$ respectively. CBE scored the last position with average $18.64 \%$ due to its poor performance in Loan to Deposit ratio and Loan to assets ratios.

\section{iii. Risk \& Solvency ratios}

The risk and solvency ratios measure the extent to which a firm relies on debt financing rather than equity financing. These ratios are also referred to as gearing, debt, or financial leverage ratios. These ratios determine the probability that the firm default on its debt contracts. The more the debt a firm has the higher is the chance that firm will become unable to fulfil its contractual obligations. The following ratios measure for risk and solvency were used for the study.

\section{a. Debt to Equity Ratio (DER)}

Debt to Equity ratio represents the degree of leverage of the bank. This ratio indicates us how the bank finance its operation with debt relative to shareholders' equity. A high value of this ratio provides indication that firm involves in more risky business.

Figure 3.2 Debt to Equity ratio

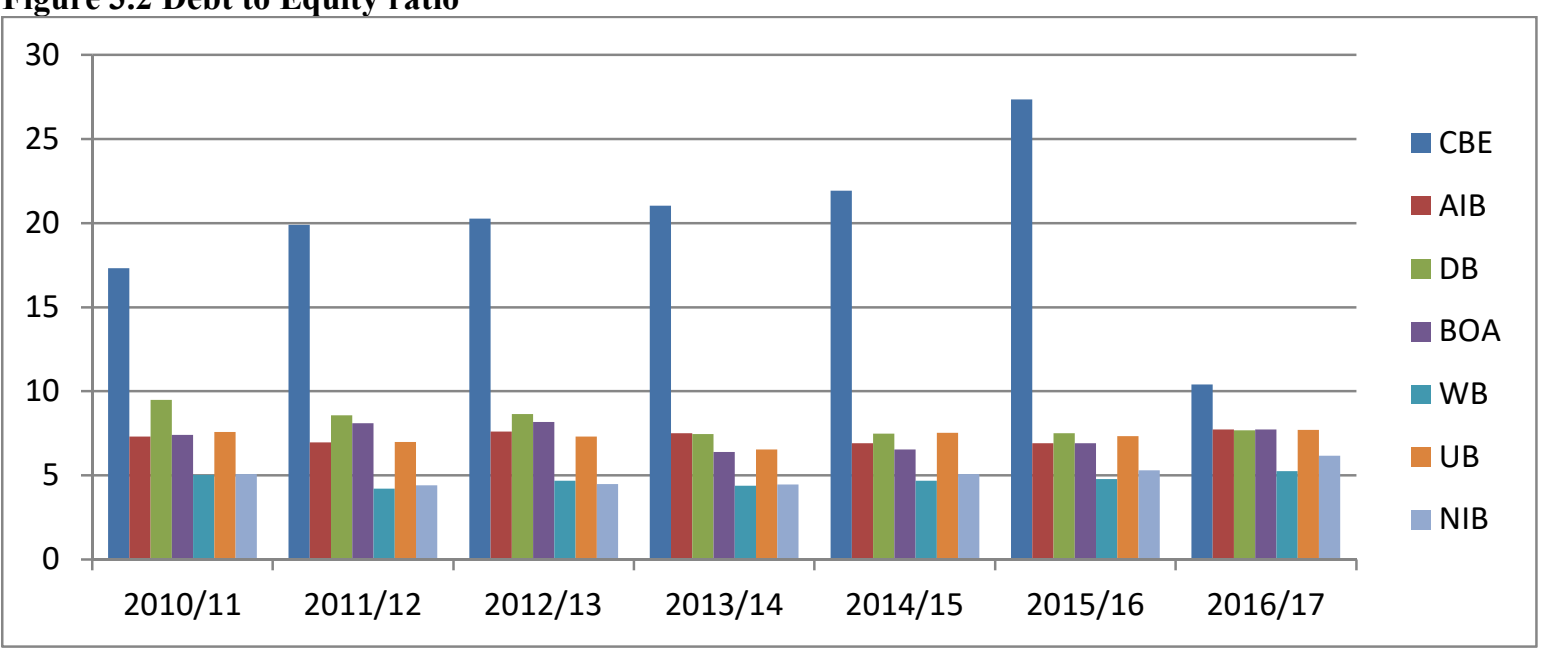

In the above figure 3.2, WB is on the top position with least average of 4.71 times followed by NIB with average of 5 times and UB, and AIB with average of 7.28 times. WB is more concerned about the protection of depositors and creditors. CBE scored the lowest position with an average of 19.75 times. The extent in which $\mathrm{CBE}$ relies on debt financing is higher than other banks reliance on debt financing.

\section{b. Debt to Total Asset Ratio (DTAR)}

DTAR also measures the ability of the bank capital to absorb financial shocks. This ratio indicates the proportion of assets financed with debt or creditors. A high value of this ratio provides indication that firm involves in more risky business. 


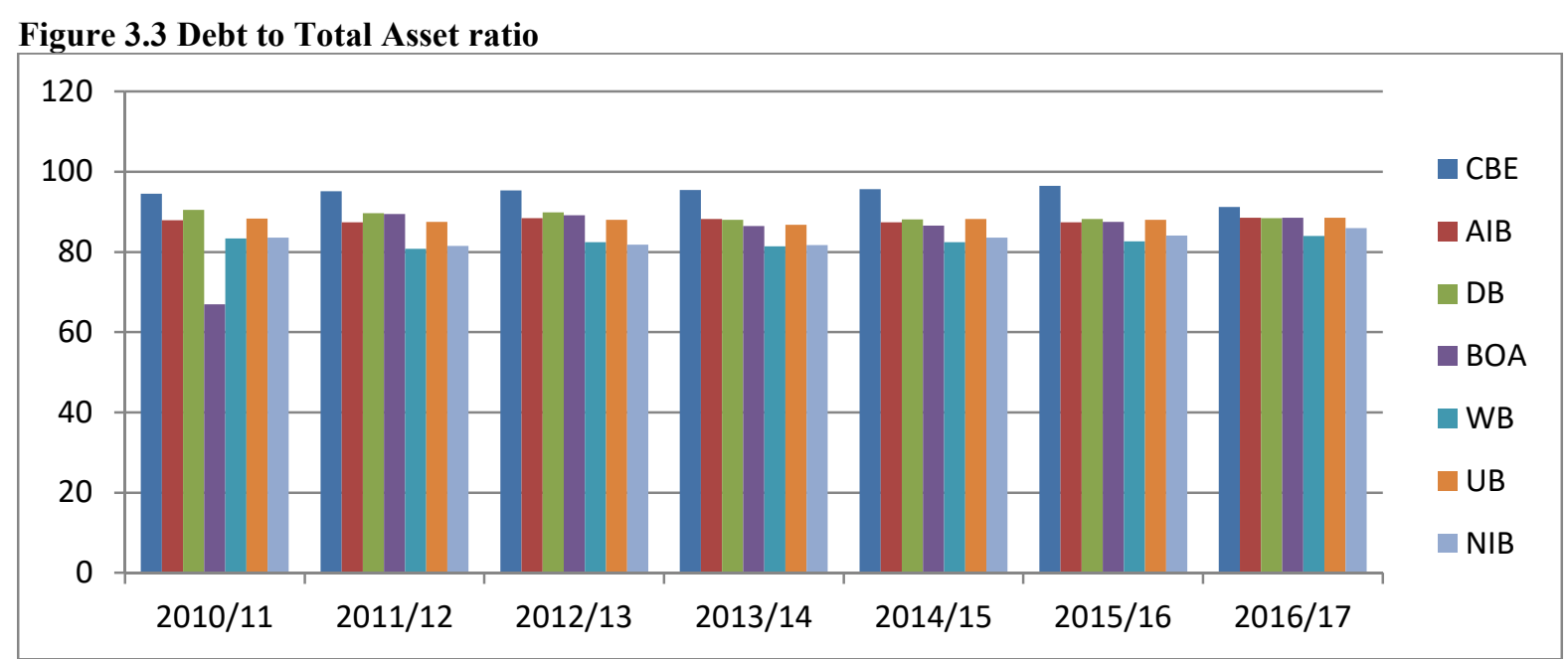

As it is evident from the above figure, WB has the least debt to total assets ratio and ranked first. WB is followed by NIB and BOA occupying the second and third position respectively. The last position regarding to DTAR is occupied by CBE. And which conforms to our results of debt to equity ratio.

\section{c. Equity Multiplier (EM)}

This ratio shows how many dollars of assets must be supported by each dollars of equity capital. The higher value of this ratio indicates signal for risk failure

Table 3.10 Equity Multiplier (In percentage)

\begin{tabular}{|l|l|l|l|l|l|l|l|l|l|}
\hline & $2010 / 11$ & $2011 / 12$ & $2012 / 13$ & $2013 / 14$ & $2014 / 15$ & $2015 / 16$ & $2016 / 17$ & Average & Rank \\
\hline CBE & 18.32 & 20.93 & 21.26 & 22.03 & 22.92 & 28.37 & 11.41 & 20.75 & 7 \\
\hline AIB & 8.30 & 7.95 & 8.61 & 8.51 & 7.92 & 7.92 & 8.73 & 8.28 & 3 \\
\hline DB & 10.50 & 9.57 & 9.63 & 8.47 & 8.48 & 8.52 & 8.67 & 9.12 & 6 \\
\hline BOA & 11.06 & 9.05 & 9.17 & 7.38 & 7.57 & 7.91 & 8.72 & 8.69 & 5 \\
\hline WB & 6.03 & 5.20 & 5.68 & 5.38 & 5.68 & 5.77 & 6.24 & 5.71 & 1 \\
\hline UB & 8.57 & 7.96 & 8.31 & 7.54 & 8.52 & 8.33 & 8.71 & 8.28 & 3 \\
\hline NIB & 6.07 & 5.42 & 5.49 & 5.47 & 6.09 & 6.29 & 7.16 & 6.0 & 2 \\
\hline
\end{tabular}

(Researcher own computation from audited financial statement)

The analysis of equity multiplier further proves WB and NIB to be less risky and more solvent as compared to the rest of the peer groups. This result is consistent with our results found in DER and DTAR for WB and NIB. Not surprisingly, WB and NIB EM is exhibiting similar behaviour as of DER, which further verifies that relative to debt, equity base is increasing more in WB and NIB due to that they ranks the first two position respectively and the last position occupied CBE because of it involves in more risky and less solvent businesses.

d. Non-performing Loans to Total Loan (NPLTL)

NPLTL ratio is one of the most important criteria to assess the quality of loans or asset of a commercial banks. It measures the percentage of gross loans which are doubtful in banks' portfolio. The lower the ratio of NPLTL, the better is the asset/credit performance for the commercial bank. 
Figure 3.4 Non-performing loan to total

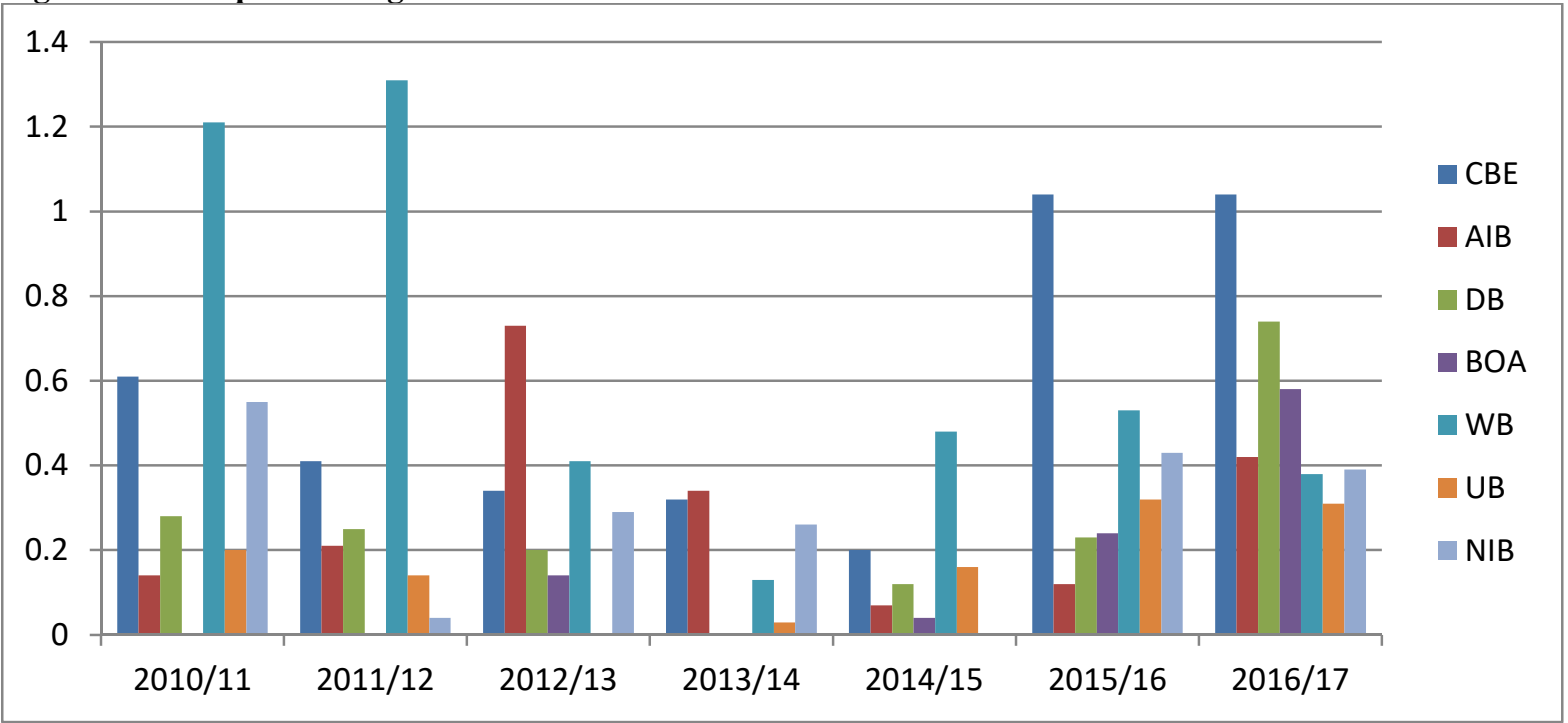

The above figure presented the trends for non-performing loan to total loan ratios. BOA demonstrated better management of its risk and solvency, and was able to get an average of non-performing loan to total loan ratios to the tune of $0.16 \%$. This is least of all banks and thus BOA is ranked first and followed by UB with an average of $0.17 \%$. The average of NPLTL ratios of WB is at $0.64 \%$ which is highest compared to other banks and is ranked last.

\section{e. Overall ranking of risk \& solvency measure}

The Group Ranking of all the selected banks under the Risk \& Solvency parameter is presented in Table 3.11. The group ranking is based on the average of individual bank's risk and solvency sub-parameter ranks. The contribution of each bank for specific sub-parameter was converted into hundred percent primarily for not affecting the contribution of one specific-parameter by the other (to make each specific-parameter independent of each other), secondly to protect their contribution for the overall risk \& solvency performance as well as the overall performance besides calculating the overall risk \& solvency result conveniently. The table below shows the risk and solvency ratios by type of banks and the overall rank position of the banks regarding to risk and solvency.

Table 3.11 overall risk and solvency measure

\begin{tabular}{|l|l|l|l|l|l|l|}
\hline & DER & DTAR & EM & NPLTL & Average & Rank \\
\hline CBE & 33.22 & 15.54 & 31.05 & 24.05 & 25.97 & 7 \\
\hline AIB & 12.24 & 14.41 & 12.39 & 12.24 & 12.82 & 4 \\
\hline DB & 13.66 & 14.58 & 13.65 & 10.97 & 13.22 & 5 \\
\hline BOA & 12.31 & 13.92 & 13 & 6.75 & 11.50 & 2 \\
\hline WB & 7.92 & 13.51 & 8.54 & 27.01 & 14.25 & 6 \\
\hline UB & 12.24 & 14.41 & 12.39 & 7.17 & 11.55 & 3 \\
\hline NIB & 8.41 & 13.63 & 8.98 & 11.81 & 10.71 & 1 \\
\hline
\end{tabular}

As it is evident from the Table above, NIB has the highest risk and solvency ratio and ranked first. NIB is followed by BOA, UB, and AIB occupying the second, third, and fourth position respectively. The last position is occupied by Commercial Bank of Ethiopia.

iv.

Efficiency Ratio

These ratios measure how effectively and efficiently the firm is managing and controlling its assets. A firm is technically efficient if it produces a given set of outputs using the smallest possible amount of inputs (Falkena et al, 2004). Outputs could be loans or total balance of deposits, while inputs include labour, capital and other operating costs.

\section{a. Asset Utilization (AU)}

This ratio measures capability of firm to generate revenue with its asset. The high value of this ratio indicates the high productivity of firm's asset. 
Table 3.12 Asset Utilization (In percentage)

\begin{tabular}{|l|l|l|l|l|l|l|l|l|l|}
\hline & $2010 / 11$ & $2011 / 12$ & $2012 / 13$ & $2013 / 14$ & $2014 / 15$ & $2015 / 16$ & $2016 / 17$ & Average & Rank \\
\hline CBE & 5.14 & 5.23 & 5.81 & 5.88 & 6.01 & 5.41 & 4.74 & 5.46 & 7 \\
\hline AIB & 6.48 & 6.29 & 5.94 & 6.54 & 6.59 & 6.56 & 6.79 & 6.46 & 6 \\
\hline DB & 6.53 & 7.52 & 6.74 & 7.14 & 7.45 & 6.97 & 7.20 & 7.08 & 3 \\
\hline BOA & 6.61 & 6.52 & 5.97 & 6.18 & 6.10 & 7.03 & 7.03 & 6.49 & 5 \\
\hline WB & 8.87 & 7.96 & 7.67 & 7.27 & 7.55 & 7.35 & 8.00 & 7.81 & 1 \\
\hline UB & 6.29 & 7.20 & 6.60 & 6.43 & 6.60 & 6.65 & 6.28 & 6.58 & 4 \\
\hline NIB & 7.55 & 7.34 & 7.29 & 7.53 & 6.85 & 6.56 & 6.75 & 7.12 & 2 \\
\hline
\end{tabular}

(Researcher own computation from audited financial statement)

Table 3.12 depicted the total revenue to total assets ratios of the selected banks. The average of total revenue to total assets ratios of WB is highest at 7.81\% amongst the group and thus ranks first and followed by NIB at $7.12 \%$ whereas the average of total revenue to total asset ratios of CBE is $5.46 \%$, which is lowest and ranked least amongst the group.

\section{a. Income to Expense Ratio (IER)}

Income to expense is the ratio that measures amount of income earned per dollar of operating expense. This is the most commonly and widely used ratio in the banking sector to assess the managerial efficiency in generating total income vis-à-vis controlling its total operating expenses. High IER is preferred over lower one.

Table 3.13 Income to Expense Ratio

\begin{tabular}{|l|l|l|l|l|l|l|l|l|l|}
\hline & $2010 / 11$ & $2011 / 12$ & $2012 / 13$ & $2013 / 14$ & $2014 / 15$ & $2015 / 16$ & $2016 / 17$ & Average & Rank \\
\hline CBE & 2.54 & 3.18 & 2.66 & 2.27 & 2.21 & 2.04 & 1.85 & 2.39 & 1 \\
\hline AIB & 2.20 & 1.91 & 1.70 & 1.81 & 1.64 & 1.57 & 1.57 & 1.77 & 2 \\
\hline DB & 1.97 & 2.07 & 1.81 & 1.81 & 1.62 & 1.53 & 1.40 & 1.74 & 4 \\
\hline BOA & 1.72 & 1.67 & 1.69 & 1.53 & 1.46 & 1.42 & 1.42 & 1.56 & 7 \\
\hline WB & 2.28 & 2.17 & 1.86 & 1.63 & 1.52 & 1.45 & 1.49 & 1.77 & 2 \\
\hline UB & 2.05 & 1.96 & 1.70 & 1.53 & 1.33 & 1.34 & 1.32 & 1.60 & 6 \\
\hline NIB & 2.10 & 2.05 & 1.80 & 1.66 & 1.57 & 1.47 & 1.54 & 1.74 & 4 \\
\hline
\end{tabular}

(Researcher own computation from audited financial statement)

On the basis of seven year average total income to total operating expense ratio Commercial Bank of Ethiopia is at the top with 2.39 times followed by Wegagen bank and Awash International Bank with 1.77 times each and Bank of Abyssinia is at the last position with the average of 1.56 times.

\section{b. Operating Efficiency (OE)}

Operating efficiency is the ratio that measures the amount of operating expense per dollar of operating revenue. It measures managerial efficiency in generating operating revenues and controlling its operating expenses. In other words, how efficient is the bank in its operations. Lower OE is preferred over higher OE.

Table 3.14 Operating Efficiency (In percentage)

\begin{tabular}{|l|l|l|l|l|l|l|l|l|l|}
\hline & $2010 / 11$ & $2011 / 12$ & $2012 / 13$ & $2013 / 14$ & $2014 / 15$ & $2015 / 16$ & $2016 / 17$ & Average & Rank \\
\hline CBE & 46.90 & 36.80 & 45.53 & 54.66 & 57.34 & 64.14 & 74.98 & 54.34 & 1 \\
\hline AIB & 58.84 & 70.25 & 79.15 & 73.48 & 84.23 & 88.14 & 84.22 & 76.90 & 4 \\
\hline DB & 68.14 & 63.26 & 77.66 & 75.52 & 83.93 & 89.49 & 97.64 & 79.38 & 5 \\
\hline BOA & 74.65 & 80.04 & 84.12 & 94.72 & 99.25 & 97.39 & 94.41 & 89.23 & 7 \\
\hline WB & 49.92 & 58.95 & 65.24 & 78.90 & 84.41 & 88.71 & 85.77 & 73.13 & 2 \\
\hline UB & 63.43 & 67.16 & 80.74 & 89.16 & 102.91 & 108.90 & 110.46 & 88.97 & 6 \\
\hline NIB & 58.18 & 60.90 & 70.94 & 77.16 & 84.55 & 93.58 & 89.36 & 76.38 & 3 \\
\hline
\end{tabular}

(Researcher own computation from audited financial statement)

When the average OEs ratio of each bank over the study period is observed CBE has least average score which makes it better performer than its competitors. Similarly, WB \& NIB stood 2nd and 3rd respectively. On the contrary, the OE status for BOA was on average around $89.23 \%$ during the study period which makes it the least performer.

\section{c. Overall ranking of efficiency measure}

The Group Ranking of all the selected banks under the efficiency parameter is shown in Table 3.15. The group ranking is based on the average of individual bank's efficiency sub-parameter ranks, but from the sub-parameters OE was transformed into a meaningful form by taking the reciprocal (1/OE) for the purpose of comparison with AU and IER. Moreover, the contribution of each bank for specific sub-parameters was converted into hundred percent primarily for not affecting the contribution of one specific-parameter by the other (to make each specificparameter independent of each other), secondly to protect their contribution for the overall efficiency performance as well as the overall performance besides calculating the overall efficiency result conveniently. The table below shows the efficiency ratios by type of banks and the overall rank position of the banks regarding to efficiency. 
Table 3.15 overall efficiency measure

\begin{tabular}{|l|l|l|l|l|l|}
\hline & AU & IER & OE & Average & Rank \\
\hline CBE & 11.62 & 19.01 & 19.73 & 16.79 & 1 \\
\hline AIB & 13.74 & 14.08 & 13.94 & 13.92 & 5 \\
\hline DB & 15.06 & 13.84 & 13.52 & 14.14 & 4 \\
\hline BOA & 13.81 & 12.41 & 12.02 & 12.75 & 7 \\
\hline WB & 16.62 & 14.08 & 14.69 & 15.13 & 2 \\
\hline UB & 14 & 12.74 & 12.05 & 12.93 & 6 \\
\hline NIB & 15.15 & 13.84 & 14.05 & 14.35 & 3 \\
\hline
\end{tabular}

As shown in the above Table 3.15, CBE ranked first in two of three efficiency sub-parameters used in this study i.e. Income to Expense ratio and operating efficiency while CBE ranked seventh in Asset Utilization ratio. The rankings of the three sub parameters are averaged out and the final group ranking is reached. CBE demonstrated excellent efficiency capability and topped the Table in the parameter of efficiency followed by WB and NIB in second and third places respectively. BOA and UB is ranked last in the group on the parameter of efficiency capability.

\section{v. Overall ranking of performance measure}

The overall Liquidity performance, profitability performance, Risk \& Solvency performance and efficiency performance of the banks for the study period (2011-2017) is exhibited in the table below based on previously calculated values of each parameters. The data was in transformed form of liquidity (1/liquidity) and, risk \& solvency (1/risk \& solvency) measures in the form of higher meaningful form for the purpose of comparison with profitability and efficiency, and also to calculate the average for the overall performance ranking result conveniently.

Table 3.16 overall ranking of performance

\begin{tabular}{|l|l|l|l|l|l|l|}
\hline & Liquidity & Profitability & Risk \& Solvency & Operating Efficiency & Average & Rank \\
\hline CBE & 10.45 & 20.08 & 7.28 & 16.79 & 13.65 & 6 \\
\hline AIB & 12.29 & 13.47 & 14.74 & 13.92 & 13.61 & 7 \\
\hline DB & 13.9 & 14.18 & 14.29 & 14.14 & 14.13 & 5 \\
\hline BOA & 15.24 & 12.16 & 16.43 & 12.75 & 14.15 & 4 \\
\hline WB & 18.88 & 14.14 & 13.26 & 15.13 & 15.35 & 1 \\
\hline UB & 15.12 & 12.59 & 16.36 & 12.93 & 14.25 & 3 \\
\hline NIB & 14.12 & 13.40 & 17.64 & 14.35 & 13.07 & 2 \\
\hline
\end{tabular}

As depicted in the table 3.16, WB ranked first for the overall ranking. NIB, UB, and BOA are ranked second, third, and forth respectively. DB, CBE, and AIB were not so successful based on the overall performance parameters and thus ranked 5, 6, and 7 respectively for the period $2011-2017$.

\section{CONCLUSION AND RECOMMENDATION}

At this point, the financial analysis has been made in attempting to draw some rough conclusions on the performance of the selected commercial banks. One of the main points to understand about the financial analysis is that all the information that would be conclusive judgment about what is going on in the company's financial statements. From the brief explanation and illustrations of seven years financial statements of the commercial banks have been used to analyse the financial performance and rank according to their performance under study period. Examination of the empirical analysis makes it possible for the study to shed some light on his findings and draw some conclusions:

On the basis of Liquidity Parameter the banks are ranked as; WB is considered to be the first one, BOA is in the second rank, UB is the third, NIB is the fourth, DB is the fifth rank, AIB is the sixth rank, CBE is in the seventh rank. Therefore, to have a satisfactory level of highly liquid assets those are easily convertible into cash to meet the unexpected loan demands, customers demand and unanticipated decline in the deposits. The entire average liquidity ratio for all banks was in a better position which is good in affecting profitability in a constructive way; however keeping more liquid asset affects the profitability position negatively for the reason that investment in liquid asset has relatively lower income than investment in non-liquid assets. Consequently, the banks CBE, AIB \& DB should reduce their liquidity ratio by revision the lending policy and the receivable collection policy.

Examination of all profitability measures, Return on assets (ROA), Return on Equity (ROE), Profit Expense Ratio (PER), Return on Deposit (ROD), and Net Interest Margin (NIM) used and indicates based on Profitability Parameter, the highest rank is CBE, DB is the second, WB and AIB are third and fourth rank respectively, NIB is the fifth, UB is the sixth and BOA is the last rank in this regard. Thus, to control the profitability position of the banks by controlling the assets quality and operating expenses which means higher interest income or comparatively lower interest expense which is charged up on the earning assets.

Analysis of the results of all the risk and solvency measures, Debt Equity Ratio (DER), Debt to Total Assets 
ratio (DTAR), Equity Multiplier (EM), and Non Performing Loans to Total Loan Ratio (NPTL) used and indicates the ranking of the banks based on Risk \& Solvency Parameter as follows; NIB, BOA, UB, AIB and DB banks are occupied first, second, third, fourth and fifth ranks respectively. WB and CBE got sixth and seventh rank in this regard. Thence, to control and administer the growth and ability to raise new capital through debt or equity which leads to give a reasonable dividend. Regarding Bad-debts and or non-performing loans, they kept under good control to attract the stakeholders of the banks. Furthermore, the performance of CBE is low in risk and solvency parameter but high in a profitability parameter. So CBE should have a more focused approach within asset quality which means the bank should balance the risk and return of investment on the banks assets.

According to the Efficiency Parameters the banks are ranked as follows; CBE got the first position WB, NIB, and DB are occupied second, third and fourth rank respectively. The ranks six and seven position are held by UB $\&$ BOA respectively in this regard. The Quality of monitoring and supporting the activities by the board and management led to the effective utilization of assets, income generation and managing expenses. Based on the efficiency values calculated, it is recommended that management of the financial segment in both BOA and UB have to be stronger in utilization of assets, in income generation and managing their expenses.

On the basis of overall performance the banks are ranked as; WB, NIB, UB, BOA, DB, CBE and AIB are occupied one up to seven ranks respectively. Overall results of profitability measures results indicate that BOA and UB are less profitable compared with the other commercial banks, therefore the bank should work on increasing the number of bank branches, increase loan financing by selling shares for the public and move towards good return because this is the means to assure its survival in the market.

\section{REFERENCE}

$>$ Brigham and Huston, (1999), fundamentals of financial management, $10^{\text {th }}$ ed books.google.com. $>$........ > corporate finance

$>$ Brigham and Huston, (1999), ratio analysis, , University of Florida, $12^{\text {th }}$ ed

$>$ Hasan, Z. (2005), "Evaluation of Islamic banking performance: On the current use of econometric models", Munich Personal RePEc Archive Paper No.6461, posted 27.

$>$ Iqbal, M. and Molyneux, P. (2005), "Thirty Years of Islamic Banking: History, Performance and Prospects", New York: Palgrave Macmillan.

$>$ Peters, D., Raad, E. and Sinkey F. Joseph (2005), "The performance of banks in post war Lebanon", International Journal of Business, 9(3), 259-28.

$>\quad$ Ross, S. A., Westerfield, R. W, Jaffe, J. (2005), “Corporate Finance.” McGraw-HillInc., 7th Ed.

$>$ Ross, Westerfield, Jordan, Robert.(2002), fundamental of corporate finance, $9^{\text {th }}$ ed www. Studymode.com/subjects/,fundamentals-of- corporate

$>$ Samad Abdus, and Kabir Hassen (2000), "The Performance of Malaysian Islamic Bank during 1984-1997: An Exploratory Study." Thoughts on Economics 10,no. 1 \& 2:

$>$ Tarawneh, M. (2006), "A comparison of financial performance in the banking sector: Some evidence from Omani commercial banks", International Research Journal of Finance and Economics, 3.

$>$ Turati, G. (2003) "cost efficiency and profitability in European commercial banking" Phd dissertation universita, cattolica del S. Coore.

$>$ Van Horne, James, and Wachowicz, John (2005), "Fundamentals of Financial Management", Pearson Education Limited, 12th Ed 